\title{
Corporate South Africa and biodiversity in a green economy
}

\author{
Anesu Makina \\ Albert Luthuli Centre for Responsible Leadership University of Pretoria \\ South Africa \\ Anesu.makina@up.ac.za
}

\begin{abstract}
Environmental protection and conservation efforts pose a major challenge the world over, more so for newly industrialising countries that need to strike the precise balance between environmental preservation and future economic development. An arduous challenge for business and the government is the reconciliation of economic growth, development and natural resources conservation. Biodiversity conservation is no longer the preserve of national organisations or state bodies. Companies as users of biodiversity and contributors to its degradation and loss should be a part of the solution as well. The general business world has since entered a new era in terms of its role in aiding and disabling the move towards sustainable development. This is partly attributed to an evolution in policy making from treating the corporation as a problem to perceiving it as a vehicle for economic development and, in this context, integral to the concept of an African renaissance. It is against this backdrop that the article takes stock of the manner with which the corporate sector is conserving and preserving biodiversity as well as methods and modes that are used to do this. It also highlights some of the theories that have been posited to do this which in turn can assist in mapping future engagement. This article aims to present a case for further including the private sector in conserving and preserving biodiversity as a sub stream of environmental issues facing the world today.
\end{abstract}


Key words: African renaissance; biodiversity; conservation of natural resources; corporate environmentalism; sustainable development in South Africa

\section{Introduction}

'No economic order can change without the lineaments of the new already being latently present within the existing state of things' (adopted after Saint Simon in Harvey 2003).

The statement above aptly sums up an inherent truth; some of the solutions that will move South Africa (and other countries) towards sustainable development and a green economy are already being implemented. It is a matter of identifying and up scaling these processes where possible. Research shows that the environment has limits, and the existing path of consumption will stretch available resources beyond the capacity of the planet. Paradoxically, environmental protection and conservation efforts pose a major challenge the world over, more so for newly industrialising countries that need to strike the precise balance between environmental preservation and future economic development. An arduous challenge for business and the government is the reconciliation of economic growth, development and the conservation of natural resources. This however is not a new type of conundrum. Many environmental problems can be termed 'wicked', in other words, involving competition among an array of goods and a multitude of perfectly legitimate interests (Rittel and Webber 1973 in Brennan 2004). Other scholars including Conklin and Weil (1997) substantiate this by saying that a wicked problem is an evolving set of interlocking issues and constraints where a linear approach to finding a solution will not bring about a resolution. This is the reason why previously unorthodox partnerships are being called to the proverbial table to find solutions. As such, the partnership between private sector and business is no longer perceived as an odd combination in terms of biodiversity conservation.

The theoretical framing of this article is African renaissance which is viewed from a green economy lens. It is against this backdrop that the manner in which the corporate sector is conserving and preserving biodiversity and methods and modes that are used to do this are explored. The article specifically responds to the following question: How does corporate South Africa, in its capacity as a major beneficiary and user of the environment, take concrete conservation action whilst remaining profitable? A literature review reveals a general dearth in information pertaining to the topic of corporate environmental action. Moreover, information on and from the global South is glaringly scarce. Apart from making a contribution from South Africa, this article also contributes to building the case for greening the economy by encouraging better biodiversity management by corporate sector players. The decision to use South Africa as an example is the author's own location. The content of the article may have an international appeal as companies that are grappling with corporate sustainability matters span the globe.

In terms of structure, this article delves into a background on the topic and defines key concepts in order to draw boundaries for discussion. The role of the state is also demarcated. This is followed by a literature review on corporate environmental action, 
business and biodiversity and a discussion on corporate social responsibility. The article concludes by building the business case for further environmental action for the transition to a green economy.

\section{Background}

The business world has now entered a new era in terms of its role in aiding and enabling the move towards sustainable development. This is partly attributed to an evolution in policy making from treating the corporation as a problem to perceiving it as a vehicle for economic development and in this context as part of an African renaissance. As a concept, African renaissance has been under discussion for a number of years with former South African President, Thabo Mbeki, credited with popularising the concept through his eminent poem-speech; 'I am an African'. It commences by stating that he is a product of the natural environment through 'the hills and the valleys, the mountains and the glades, the rivers, the deserts, the trees, the flowers, the seas and the everchanging seasons that define the face of our native land' (Mbeki, 1996 in Mbeki 2004: 9) thus giving credence to the role of nature and prominence to biodiversity. It has since turned into an ideological concept and can be theorised as a situation that strives towards African unity which can be related to the rise in the contemporary period of regionalism, the changing role of the nation state, the ascendancy of the market and the existence of a vast African Diaspora (Tikly 2003). The concept also espouses economic elements such as 'the initiation of sustainable economic development' (Taylor and Williams 2001:267). The role of corporate South Africa can thus not be neglected in any discussion pertaining to the economy since companies are economic institutions. Moreover, in recent years there has been a rise in the concept of a green economy as an engine for growth and prosperity. There is a plethora of literature on the green economy, necessitating a definition in order to locate the topic which is discussed in this article. The green economy is based on sustainability and ecological economics which, compared to preceding development pathways, is distinct in that it can directly turn natural capital into economic value whilst simultaneously maintaining it, and even conduct total cost accounting (UNEP 2011). It can be juxtaposed with business-as-usual policies that make conservation financially unprofitable and economically non-viable. By situating it within the ambit of an African renaissance, the green economy can be defined as an economic trajectory which 'results in improved human well-being and social equity, while significantly reducing environmental risks and ecological scarcities' (UNEP 2011:1).

Trends show that fundamental and structural shifts regarding environmental and natural resources management, however, generally relate to climate change. The spillover into the biodiversity space has been sluggish, in part owing to much work on biodiversity being in the natural sciences realm, with a small offering from the fields of management, organisation and social sciences. Biodiversity conservation is no longer the preserve of national organisations or state bodies. Since companies are users and contributors to the degradation and loss of biodiversity, they should be a part of the 
solution as well. However, the conceptual foundations of business and biodiversity are still in the embryonic stage. Houdet (2008) notes that it was only in 2005, the year of the UNESCO (Paris) Conference on 'Biodiversity, Science and Governance', that biodiversity began to be demystified within the business fraternity. Prior to that, biodiversity-related corporate action was usually through the support of campaigns on wildlife or the conservation of exotic, rare species. Still, a large proportion of work in this area is found in 'grey' literature, such as non-governmental organisation (NGO) reports and workshop proceedings that are not commonly available on academic search platforms. Contemporary global efforts towards biodiversity management are growing. The international study on the Economics of Ecosystems and Biodiversity (TEEB) and the establishment of the Intergovernmental Panel on Biodiversity and Ecosystem Services (IPBES) suffice as evidence.

Over the last few decades companies have begun to consider environmental concerns in their corporate and marketing strategic decisions. The business sector has now begun to consider the risks and opportunities posed by biodiversity loss. Opportunities derived from biodiversity and ecosystem services (BES) include new business streams, new products and new markets as well as cost savings and good reputation. The risks have been noted as legal, regulatory, operational, reputational, market-related, and financial (Bishop et al. 2010). Alongside the benefits for good biodiversity practices is growing pressure from a wide range of stakeholders (not limited to investors, shareholders, state and non-state actors) which is compelling companies to take responsibility for environmental impact. Biodiversity is therefore gaining prominence on the environmental agendas of corporate firms as it underpins the provision of ecosystem services and goods. Biodiversity ecosystems services (BES), referred to above, are those goods and services that are essential for human survival and can be divided into four broad areas, namely, provisioning services (e.g., food, fresh water, fish, medical and beauty plants, timber), cultural services (e.g., spiritual, ceremonial), supporting services (e.g., nutrient cycling, forest generation, natural hazard regulation) and regulating services (e.g., pollution, biological pest control, waste assimilation, natural climate regulation) (Bishop et al. 2010). Despite all these critical services, the earth's natural capital profile and resourceuse patterns lean toward a dire form of affairs, categorised by steady depreciation through severely degraded ecosystems and significantly altered biodiversity. In fact, for a country such as South Africa which ranks as the third most biologically diverse country in the world, its 2011 National Biodiversity Assessment Report highlights the fact that whilst most ecosystems in the country are depleted, wetlands are the most threatened of all the nation's ecosystems, with $48 \%$ found to be critically endangered. About $40 \%$ of terrestrial ecosystem types is threatened with $9 \%$ credited as critically endangered, $11 \%$ endangered and 19\% vulnerable (Driver et al. 2012). Degradation continues not from new processes but from the expansion and intensification of operations such as construction, extractive industry and agriculture, activities essential for the social and economic prosperity of any country thus causing a quandary for businesses, society and governments alike. Business activities play a major role in biodiversity loss so firms are under increasing pressures from stakeholders to mitigate their negative impact on 
ecosystems. The case of South Africa illustrates a paradox that is also found in many other parts of the world. If biodiversity is the sine qua non for human survival, then why is it continually used as a 'free' good despite mounting evidence that there is nothing 'free' about it?

\section{When the state is not enough}

In management literature, the notion of environmental stewardship is often applied to businesses in the private sector, and government is often ignored (Siddiqui 2013). The state, however, remains the primary custodian of the environment, but it is widely accepted that the government more often than not, lacks the capacity to implement and monitor all activities even where legislation exists in perfection. This has given rise to 'informal policing' by an array of actors in the environmental conservation space - ranging from civil society, to concerned individuals and even business firms. The emergence of new forms of environmental ethics during the past few decades has provided a platform for demonstrating that nature is worth preserving for its own sake, not just for usefulness to humans (versus anthropogenic). However, this moral crusade to conserve the intrinsic value of nature in all its forms conflicts with its commodification, associated with economic rationalism and the anthropocentric basis of many existing legal and political instruments and institutions (Brennan 2004). This is perhaps where the private sector as users of biodiversity services should join hands.

From a national lens, section 24 of the South African Constitution stipulates that everyone has the right to an environment that is not harmful to their health or well-being; and the right to have the environment protected, for the benefit of the present and future generations, through reasonable legislative and other measures that prevent pollution and ecological degradation, promote conservation and secure ecologically sustainable development and use of natural resources while promoting justifiable economic and social development (Republic of South Africa 1996). The ability of the state to guarantee these rights falls under the broad debates about so-called third-generation human rights, and does not form part of the discussion in this article. Nevertheless, the government is obligated to respect, protect, promote and fulfil this right though it requires financial and technical resources as well as leadership and capacity which may be lacking.

As mentioned, South Africa is a globally recognised megadiverse country. This rich biodiversity underpins and supports the country's social and economic development in numerous direct and indirect ways. This capacity to deliver is already under stress due to climate change and depletion so in the coming years will require extraordinary adaptation. South Africa is thus in a precarious position, to be a middle income, emerging economy at such a time when the environmental limitations are posing a threat at global, continental and even national levels. Politically, the country is committed to halting the degradation of biodiversity through being a signatory of numerous conventions, the United Nations Convention on Biological Diversity (CBD) being the most prominent. Furthermore, South Africa plays a prominent role in global 'green' politics as a member and current chair (as of 2012) of the Group of Like-Minded Megadiverse Countries. This 
rise of the 'greenies' and the 'green agenda' is poised to bring to the fore biodiversity as an area that needs further attention in the corporate sector as a partner to the government.

Environmental regulation as traditionally applied in South Africa is buttressed by sector specific legislation on the environment and presents a problem in relation to corporate behaviour. The challenge is that the law has not succeeded in curtailing corporate biodiversity destruction nor has it promoted better corporate environmental stewardship. This situation therefore validates an alternative approach for the realisation of better environmental action. An approach could be for organisations to proactively integrate, streamline and manage biodiversity concerns as part of standard business and decision-making processes. This can result in a win-win situation where environmental excellence and sustainability are achieved.

\section{Corporate environmental action in South Africa}

Businesses, especially the large multi nationals (or large nationals), are important owing to their role as economic engines, so it is imperative to ensure that they are operating in a sustainable manner. In keeping with international trends, biodiversity is increasingly recognised by the business community as an important issue that poses both operational risks and opportunities. Poor biodiversity management can attract fines, result in the loss of a legal and social licence to operate, customer dissatisfaction, low employee morale as well as increases in the cost of capital (Athanas 2005; Parr and Simons 2007). Ironically, biodiversity and environmental action in general are treated as external factors in business and somewhat peripheral.

From a theoretical viewpoint, there have been attempts to create a positive business case for biodiversity such as, for instance, the Porter Hypothesis, which questions the orthodox economic views about the negative causality between competitiveness and the internalisation of environmental concerns. Proponents of this hypothesis (or versions of it) invoke it to persuade the business community to accept environmental regulations as a benefit. Advantages commonly put forward include reduced energy and material consumption which translates to reduced costs, better corporate image, access to new markets, technological innovation and first mover advantage (Houdet et al. 2012; Ambec et al. 2013).

Coupled with theory, there have been active attempts in practice to embed environmental issues. The importance of biodiversity on the corporate agenda is evidenced by the number of recent initiatives that also indicate collective action. Internationally, the Swiss food group, Nestlé Waters, pays the landowners in the vicinity of its Vittel water source in north-eastern France to assist with preventing nitrate contamination of the springs and to maintain the ecosystems supporting them; and since 2007, Coca-Cola has been working with the environmental organisation, World Wildlife Fund (WWF), to conserve key watersheds and improve the efficiency of its water use (Bayon and Jenkins 2010). In South Africa, the WWF's Biodiversity \& Wine Initiative is one of the more prominent partnerships between the industry and the conservation sector. As demonstrated by the proliferation of organic ranges in food stores, ethically produced 
clothing as well as environmentally friendly detergents, the fast moving consumer goods (FMCG) sector has experienced customer willingness to pay a premium for products that have positive implications for social, environmental and governance factors including biodiversity. Retailer Pick 'n Pay, for example, noted a 266\% increase in profit on their green range in the 2012/2013 reporting period (Pick 'n Pay 2013). A South African consumer study conducted in 2011 by Ogilvy Earth found that $85 \%$ of those interviewed would boycott a company or brand on suspicion of irresponsible or damaging action towards its employees, local communities or the environment. Reinforcing this is the fact that over three-quarters of people (76\%) interviewed expressed a willingness to pay a little more for a product or service that was ethical in its social, environmental and general business practices (Ogilvy Earth 2011). Of course eco-consumerism is not without pitfalls (see Porrit 2001: 6; Dauvergne and Lister 2010).

Whilst concrete national and international examples on harmonious relations between biodiversity and businesses do exist, gaps in relation to forging a solid business case still persist. For example, for those companies that do not impact directly on BES through their operations, the biotic aspects of the business site is often neglected as a site for positive environmental action, in other words, the flora and fauna and the landscape they inhabit (offices buildings, shops) tend to be neglected (Snep et al. 2009). Biodiversity loss and ecosystem decline cannot be considered in isolation from other trends such as growing and shifting markets (organic food, increased need for fish), resource exploitation and climate change. Biodiversity loss also contributes to these trends; hence the need for integrated business responses (Bishop et al. 2010).

Empirical data shows positive changes in business attitudes, policies and behaviour regarding the environment making it worthwhile for a nuanced understanding of how business strategies may be framed and implemented. Numerous articles have been published focusing on various business typologies of environmental strategies. Forbes and Jermier (2010) observed the rise in the calls for business to take a key leadership position in addressing environmental affairs. They term this development the 'New Corporate Environmentalism' (NCE), which differs from traditional corporate environmentalism that is focused purely on compliance with environmental laws and regulation (Forbes and Jermier 2010). Corporate environmentalism can be considered as the duty to cover the environmental implications of a firm's operations, products and facilities; reduce waste and emissions; maximize the efficiency and productivity of its resources; and minimize practices that might deter the enjoyment of the country's resources by future generations (Mazurkiewicz 2004). This definition closely mirrors the famous Brundtland report definition and is in line with the notion of African renaissance.

Corporate environmentalism is a broad concept and could neglect biodiversity or even aspects of biodiversity. For example, there is the proliferation of climate change initiatives based on the reduction of greenhouse gas emissions, yet there are no complementary processes for biodiversity. Whilst much of the contemporary corporate action in South Africa has been on climate change, biodiversity is gaining currency. In accounting terms, the non-fungibility of biodiversity is what differentiates it from climate change for which an accounting unit (carbon) is available. Biodiversity is seen 
as an exogenous constraint, best addressed by helping to preserve 'charismatic' species in return for positive publicity (Houdet 2008).

Inconsistencies such as the one above have propagated interest in studying the role and actions of business actors in relation to corporate citizenship, specifically environmental impacts and concerns. This in turn has promulgated new theories on business strategies towards environmental issues. For instance, Houdet et al. (2009) illuminate work by Jolly (1993), which proposes three types of arbitrage that drive business eco-behaviour, that is, (a) eco-defensive, focusing on immediate economic returns and considers environmental investments exclusively as costs; (b) eco-compliance, which seeks to do no more than satisfying regulatory norms; and (c) eco-sensible, which strives to go beyond legal requirements, viewing environmental concerns as key to the viability of the business. When analysing business attitudes and actions towards biodiversity, most companies lean towards one of the three aforementioned typologies. The problem, as Forbes and Jermier (2010) have reasoned, is with the existing structure of commerce, and not as much with ethics. Radical redesign of institutions through an integrated system (economic, biologic, and human) may be a step to ensure positive action. This cannot be achieved at the company level alone. It needs the state to perhaps define parameters for actions in those key industries that either have a high impact on or are highly affected by biodiversity and demand action. This is where corporate environmental action can be useful in greening the economy. Biodiversity needs to be acted upon as a 'sum of the whole' through the business process. The concern for academics, policy makers and civil society alike is that companies can and sometimes do neglect the strategic importance of better environmental practices by merely relegating the duties to the corporate affairs officer or to a public relations firm. Companies need to demonstrate support for their reporting commitments with concrete, measurable, verifiable action in order to exercise true corporate responsibility. Recent evidence suggests that if reporting on sustainability reflects the action on the ground, then many organisations fall short of providing the detailed information needed for investment or decision-making. An overview of annual reports by the author for a different research process showed that traditional players such as the large mining companies paid more attention to biodiversity than the financial sector, yet each sector contributes to the depletion and exploitation of biodiversity either on a small or large scale.

This article attempts to bridge the gap among policy makers, civil society and businesses actors - a convoluted task given the competing agendas of the diverse groups aforementioned. Adding to the complexity of this task is the delicate nature of biodiversity. Human beings as yet do not possess sufficient knowledge about the intricate operations of the natural environment. Biodiversity regulations tend to reflect a reductionist view in which diversity is equated simply to the number of species. For threatened species, this is a beneficial process but it neglects the manner with which ecosystems function and the diversity between species within each habitat (Houdet 2008). For example, if one adopts the 'butterfly effect' derived from chaos theory, which posits that a small change in one place can cause a change somewhere else, one can see that social and economic activities would have to come to a grinding halt if biodiversity 
is to be arrested and reversed. There should be a shift to restorative development and the promotion of the restorative economy given the depletion of natural capital and the dawn of the ecological age (Forbes and Jermier 2010). In order to do this, emergent theories need to undress present modes of 'greenwashing'. Take, for instance, a company in extractive industries that will destroy habitats but support conservation efforts elsewhere through its corporate social responsibility processes. This approach regresses advances in thinking back to fortress conversation methods which are losing their lustre in environmental protection circles in favour of either community-based approaches or mixed methods that combine the two (see Hulme and Murphree 1999). It (greenwashing) tends to reduce business processes into silos, overlooking the fact that at each stage of the life cycle of a product or mode of production, there is interaction with biodiversity as well as points of entry for conservation and preservation efforts.

\section{Business and biodiversity}

A growing number of companies in a range of sectors are beginning to discover tangible value and competitive advantages from taking on environmental initiatives. In the area of pollution prevention, energy efficiency, environmentally oriented design, supplychain management and industrial ecology, companies have been able to not only avert risks but also to find ways of capitalising financially (Mazurkiewicz 2004). Corporate citizenship is an inherently multi and interdisciplinary concept that requires attention from sociologists, development scholars, management practitioners and others. This is more so in view of the growing nexus among corporate citizenship, environment and biodiversity; relatively new areas in academic literature (Hamann 2006). Establishing a business case for involvement in the biodiversity arena in particular has not been smooth despite that the activities of companies have a huge impact on natural habitats. Business in its myriad forms is primarily responsible for ecological plunder; it is therefore appropriate that companies inquire on the best ways in which to conduct operations honourably in these latter days of industrialism that perhaps mark the beginning of an ecological age (Hawken 1993). Critically, concepts of leadership in this arena often infer that the previous manner of conceptualising policies may need an overhaul to accommodate new pathways. Over and above the importance attached to the need for a growing private sector for increased employment opportunities and investments, there is a relatively novel emphasis on the private sector itself and the role it can or should play in sustainable development and environmental action (Hamann 2006). A positive spin has been the adoption of Decision VIII/17 to further involve the private sector in the activities of the Convention on Biological Diversity (CBD) in 2006 (Houdet et al. 2012). This decision primarily aims at improving the regime's legitimacy. By increasing business involvement, Decision VIII/17 can be viewed within the context of the prevailing academic debate on the 'privatisation' of environmental governance, which refers to the growing importance of private actors in the formulation of environmental policies (Bled 2009). Civil society remains conflicted on the best methodology with which to engage the private sector as they abhor the general perception 
that business leaders have privileged access to politicians by virtue of the rent- seeking nature of businesses as wealth creators (Porritt 2001).There has also been scepticism by developing country governments who warned state parties about the 'entry of the foxes in the henhouse', advising a cautionary approach to dealing with business (Bled 2009:154). The involvement of private sector actors is deemed controversial, owing to the pursuit of profit maximisation and links to powerful elites (Bled 2009:156). This is one of the criticisms that has supported the impression that the private sector has unrestricted access to the environment. Porritt (2001) asserts that, while legislation has always defined the permissible level of cost externalisation, too often state actors endorse the narrow interests of industrialists at the expense of the environment and society. Business actors have grown to relish a 'licence to pollute' for so long that it has become embedded in development planning as an expectation it is a system that appears daunting to reverse. Whilst there exist valid debates for both the inclusion and exclusion of the private sector, the reach, scope and intensity of their activities warrant their involvement, if not for anything but increased awareness.

Discourse pertaining to the reasons and extent of business involvement in society and development matters has been largely normative in nature. The landscape has been dominated by rather critical attitudes towards business with the debates revolving around the ideological divide between business oriented 'capitalist thinkers' and 'critical', 'liberal' or 'socialist' proponents of stronger responsibility (Matten et al. 2003).

The role for big business is evolving to the realisation that profit, economic growth and environmental protection can and should operate in synergy. There is still scope for further work to highlight these synergies partially owing to the ostensible persistence of the world's modern environmental and social problems vis-à-vis the slow response of business and the state to these problems (Forbes and Jermier 2010). Civil society grudgingly looks to the private sector to play a benign role in assisting government to meet its developmental aspiration, often urging the uptake of quasi-governmental roles (Porritt 2001). Emerging paradigms and analytical frameworks as a result postulate a role for corporate sector engagement in biodiversity matters in the ambit of responsible leadership or corporate citizenship; where organisations act in cooperation with the government, stakeholders and local communities at national, regional and international level. Action should transcend beyond an individual sector.

Where historically 'the environment' was perceived by business as only related to burdensome and restrictive environmental law regulations, both business and investors now realise the need for sustainable ecosystems (Houdet et al. 2012). It has since been discovered that enhancing biodiversity can avail entrepreneurial and investment opportunities (Bishop et al. 2010; Lambooy and Levashova 2011). Still, some scholars working on environmental sustainability have generated cynicism concerning motives underlying corporate environmentalism (Forbes and Jermier 2010). Environmental issues, notably industrial and regulatory norms, are often treated as external constraints as they necessitate substantial investments to bring forth minimal or negative returns, aside from associated decreases in productivity (Houdet et al. 2009). Other scholars have presented a more sanguine front about green corporate action, engaging in the variety 
of ways in which this could be achieved whether through taxation, self-regulation or certification (Bishop et al. 2010; Forbes and Jermier 2010). The debates on the nexus between the private sector and biodiversity have been revitalised, given new attention from a fresh perspective to that which was prevalent when mainstream thinking began.

This reinvigorated interest in engaging the private sector is to a degree due to the realisation that the path from policy formulation to execution has not borne the requisite results. In other words, despite a strong legal framework, biodiversity degradation has been neither halted nor reversed. By neglecting relevant stakeholders, programmes and policies will likely continue to not pan out in the manner envisioned or intended. As large users of biodiversity, businesses should therefore be included, although research is still required to ensure that business engagement within this arena yields the expected results and that the resources poured into the process are not wasted.

The acceptance that collective action is required to solve 'wicked problems', has been one of the anchors for the case for the promotion of private sector development in its role beyond employer and investor to environmental defender. The need to change the perception of businesses as environmental degraders to business as environmental champions through the promotion of sound modes of production and ethical consideration along (global) supply chains is slowly manifesting (Prieto-Carrón et al. 2006). Notwithstanding the sceptics, biodiversity has emerged on the corporate agenda as both a risk and an opportunity that must be managed through more rigorous impact assessments and environmental management systems (Athanas 2005). The involvement of the private sector in the elaboration of norms intended for controlling its activities is rightly questioned, yet it is the value of including this sector in environmental initiatives that could yield the desired benefits and thus should be seen as part of the solution (Bled 2009).

\section{The role of corporate social responsibility in greening corporate activities}

Of the numerous perspectives that have been purported forth to include environment, society and governance (ESG) into private sector business streams, Corporate Social Responsibility (CSR) has emerged among leading firms and business schools as the prime public relations tool to deflect criticism, engage critics and potentially capitalise on opportunities associated with doing, and being seen to be doing, good (Newell and Frynas 2007: 670). Historically social issues were anchored in CSR while environmental issues were in environmental management (EM). In recent years, Corporate Sustainability (CS) which includes social and environmental issues has entered the scene, blurring research boundaries yet working towards the common goal of promoting responsive corporate citizenship (Montiel 2008).

According to Mazurkiewicz (2004), too often, CSR is understood from the perspective of businesses funding community projects (philanthropy). Such conceptualisation fails to capture the most valuable contributions that companies can make through modified behaviour and good business conduct. From a terminology perspective, CSI (Corporate 
Social Investment), CS (Corporate Sustainability) and CSR tend to be understood and used interchangeably by both society and firms. Taking the example of 112 U.S. companies enrolled in the Global Reporting Initiative (GRI), various expressions were used to refer to companies' social and environmental reports including the 'Global Citizenship Report', the 'Corporate Responsibility Report', the 'Environmental Sustainability Report', the 'Sustainability Report' and the 'Environmental \& Social Responsibility Report' (Montiel 2008). The situation in South Africa was no different prior to 2009; nevertheless, since the 2010/2011 reporting period, there has been a general standardisation of terminology usually titled 'integrated report' or 'sustainability report'. According to Mazurkiewicz (2004), since its development in the 1970s, there has been no commonly accepted definition of Corporate Social Responsibility (CSR). Prieto-Carrón et al. (2006) concur that as an evolving concept, CSR is complex; it includes a growing range of matters on the role of business's relation with society. Newell and Frynas (2007: 673) use the European Commission's definition of CSR which is 'a concept whereby companies integrate social and environmental concerns in their business operations and in their interactions with their stakeholders on a voluntary basis'. This definition supports the foregoing in that CSR can be anything a company wants whether it be philanthropy, environmental protection, paying fair wages along the supply chain or even infrastructure projects.

The drivers of CSR as an ESG strategy stem from a mix of incentives and risks directed at companies to improve standards. These drivers are market-based, usually beginning when a firm anticipates or responds to a risk associated with the social, labour or environmental impact of a specific practice (Mazurkiewicz 2004). From a citizenship standpoint, CSR should not be treated as a favour 'done to' communities by organisations. Rather, as the results of environmentally unsound processes begin to slip into society through higher water bills and electricity as well as fuel shortages, it is likely that the state will put immense pressure on companies which may curtail operations altogether. In South Africa, there are a number of forces that have contributed to the CSR agenda. Apart from the socio-economic status of the country, business is also obliged to subscribe to an assortment of standards and guidelines for mandatory or voluntary sustainability reporting such as the King Reports on Corporate Governance and the Global Reporting Initiative (GRI). The most important and relevant in the South African context are perhaps the King Codes on Corporate governance, and more recently the 2010 King III Code which not only stresses that sustainability, governance and strategy are inextricably intertwined but requires companies to provide integrated reports. Compliance to this Code is mandatory for all Johannesburg Stock Exchange (JSE) listed companies; this in turn has seen a fluency in the sustainability languages.

The social aspect of CSR has been 'nailed' by some organisations while the uptake remains uneven for environmental issues relating to biodiversity in particular. Climate change is faring much better, because it translates to the need to reduce energy consumption which in turn reduces costs. Within academic circles, the promotion of environmental stewardship extending beyond government to corporations is palpable in discourse. Environmental stewardship as it relates to corporations means that organisations have 
a duty to do no harm, through adherence to the law or internal guidelines and also by ensuring minimal environmental damage if the laws are lacking or not enforced, i.e., acting in an environmentally responsible/ethical manner in the absence of law enforcement. Likewise, companies are expected to make environmentally sound tradeoffs. For example, if there is a choice between preserving a pristine quality wetland by not mining low grade ore, the expectation is that the wetland would be preserved. However, there exists a myriad of potential (social) projects, which firms that are not directly impacted (or directly impact on) by biodiversity may prefer to use their 'social spend' because assurance for biodiversity processes, especially along the supply chain, is costly. In Knorringa and Helmsing (2008), this point is substantiated by arguing that CSR aims to show stakeholders that the company behaves in a responsible manner yet the major societal issues it was intended to tackle are not illustrated.

Business legitimacy can hinge on better biodiversity practices as this can assist with reputation management. The need to secure social licence and manage reputation for companies in the extractive industries cannot be emphasised enough, if the stubbornness of Shell's reputation in Nigeria is a precursor. Self-regulation has been evident with some companies that have developed internal guidelines for environmental management. The proliferation of positive action by big business is a passable rebuttal to the Milton Friedman rhetoric 'the business of business is business' (Porritt 2001). It comes as no surprise that some companies still operate 'wild west' style, with no regard to current legislation, let alone voluntary self-regulation. This, for a couple of reasons, poses a complex challenge for the state and those companies that do comply. First, the operational rents for a complying company are far greater than those of a company that does not comply, suggesting unfair competition. Secondly, and perhaps importantly, where resources are shared due to proximity, responsibility processes can be counterproductive. To extrapolate, using the example of a shared water stream by a mining concern, if a company upstream purifies water, it will be re-contaminated if the operator downstream does not follow suit with the purification process. Either vicious or virtuous cycles can arise from the insistence of environmentally sound practices without the adequate structures on the ground to assess potential bottlenecks. Action concerned with biodiversity may also be costly to smaller companies thus potentially creating monopolies in industries in favour of those firms that can afford to hire ecologists and biodiversity specialists. Corporate environmental initiatives still remain context specific: working for some firms, in some places, tackling some issues, some of the time, the impetus is for researchers to continue seeking best practices and for industry practitioners and policy makers to explore a variety of options for a 'best fit' (Newell and Frynas 2007: 674). The involvement of business should not be considered a 'magic bullet' for biodiversity conservation and preservation although it can necessitate an important precondition for progress (Bled 2009). Biodiversity should not be viewed as a new dimension to navigating corporate environmentalism. Rather, if environmental issues are implemented in totality, along all aspects of businesses operations, there is a chance that positive action on conservation and protection will come about. As Bled (2009) argues, CSR underlines the fact that the responsibility in the implementation of 
biodiversity conservation does not only lie exclusively in the hands of governments but also in those of business and civil society in a collaborative effort.

\section{Conclusion}

The article's objectives were two-fold: first, to showcase the current role of corporate South Africa in biodiversity conservation and preservation. The second was to highlight some of the theoretical debates prevailing in the corporate sector regarding environmental action. These theories and concepts provide a glimpse into the future with regard to how practitioners are thinking about these topics. The article has located the above objectives in the context of a green economy, a term that had gained colloquial currency in the potential direction that economics around the globe will have to take. The notion of an African renaissance can benefit from elements of the green economy such as good environmental and social inclusivity which in turn may see African countries 'leapfrogging' to sustainable practices. The question that the article has endeavoured to answer was: how does corporate South Africa, in its capacity as a major beneficiary and user of the environment take concrete conservation action whilst remaining profitable? Whilst a few examples were provided to illustrate the situation on the ground, both theory and practice are in the early stages. Therefore, these examples can be taken as anecdotal with a potential for up scaling (context dependent).

Greening an economy is no easy feat since this involves a complete overhaul of core processes of capital accumulation and a change in the pathway that has been in operation since the industrial period. Transforming good environmental practices from ancillary matters to core private sector operations is an area that is increasingly becoming important with more research added to this topic each year as are partnerships and initiatives among businesses and academia, NGOs and states. At the heart of building a business case is striking the balance between profit maximisation, high investor return and ecologically sound development. Unfortunately, biodiversity is yet to be considered a material matter for many industries. The article highlights the prevailing discourses pertaining to environmental action from the angle of corporate citizenship. It draws attention to the various terminologies that encompass ESG matters and accepts that the differentiation is a matter of semantics. Biodiversity as an element of CSR, while useful in that it has potential to bind companies to action, may take resources away from social and community development matters if the budget is limited and the two matters cannot be addressed simultaneously. This makes the green economy complex because it is not defined by environmental issues alone but by shifts in social processes as well. For an emerging global 'green' leader, South Africa has the opportunity to set the stage on how biodiversity and environmental issues as a whole can be mainstreamed by the private sector.

\section{References}

1996. Constitution of the Republic of South Africa, Act 108 of 1996. Pretoria: Government Printers. 
Ambec, S., Cohen, M.A., Elgie, S. and Lanoie, P. 2013. The Porter Hypothesis at 20: Can Environmental Regulation Enhance Innovation and Competitiveness? Review of Environmental Economics and Policy 7: 2-22.

Athanas, A. 2005. The role of business in biodiversity and impact assessment. Impact Assessment and Project Appraisal 23: 29-35.

Bayon, R. and Jenkins, M. 2010. The business of biodiversity. Nature 466: 184-185.

Bishop, J., Bertrand, N., Evison, W., Gilbert, S., Grigg, A., Hwang, L., Kallesoe, M., Vakrou, A., Van der Lugt, C. and Vorhies, F. 2010. TEEB-The Economics of Ecosystems and Biodiversity Report for Business. Executive Summary.

Bled, A.J. 2009. Business to the rescue: Private sector actors and global environmental regimes' legitimacy. International Environmental Agreements: Politics, Law and Economics 9: 153-171.

Brennan, A. 2004. Biodiversity and agricultural landscapes: Can the wicked policy problems be solved? Pacific Conservation Biology 10: 124.

Conklin, E.J. and Weil, W. 1997. Wicked problems: naming the pain in organizations. (White Paper): Group Decision Support Systems. http://kodu.ut.ee/ maarjakr/creative/wicked. pdf (accessed 29 October 2014).

Dauvergne, P. and Lister, J. 2010. The prospects and limits of eco-consumerism: Shopping our way to less deforestation? Organization \& Environment 23: 132-154.

Driver, A., Sink, K., Nel, J., Holness, S., Van Niekerk, L., Daniels, F., Jonas, Z., Majiedt, P., Harris, L. and Maze, K. 2012. National Biodiversity Assessment 2011: An assessment of South Africa's biodiversity and ecosystems. Synthesis Report, South African National Biodiversity Institute and Department of Environmental Affairs, Pretoria, 1- 200.

Forbes, L C. and Jermier, J.M. 2010. The new corporate environmentalism and the ecology of commerce. Organization \& Environment 23: 465-481.

Hamann, R. 2006. Can business make decisive contributions to development? Towards a research agenda on corporate citizenship and beyond. Development Southern Africa 23: 175-195.

Harvey, D. 2003. The right to the city. International Journal of Urban and Regional Research 27: 939-941.

Hawken, P. 1993. The ecology of commerce: A declaration of sustainability. New York: Harper Business

Houdet, J. 2008. Integrating biodiversity into business strategies. The Biodiversity Accountability Framework. Paris: FRB-Orée.

Houdet, J., Trommetter, M. and Weber, J. 2009. Changing business perceptions regarding biodiversity: From impact mitigation towards new strategies and practices. Paper number 2009-29. Ecole Polytechnique, Department of Economics. http://www. naturalvalueinitiative.org/download/documents/2009/oct/Changing_Business-Perc eptions.pdf/ (accessed 29 October 2014).

Houdet, J., Trommetter, M. and Weber, J. 2012. Understanding changes in business strategies regarding biodiversity and ecosystem services. Ecological Economics 73: 37-46.

Hulme, D. and Murphree, M. 1999. Communities, wildlife and the 'new conservation' in Africa. Journal of International Development 11: 277-285.

Lambooy, T. and Levashova, Y. 2011. Opportunities and challenges for private sector entrepreneurship and investment in biodiversity, ecosystem services and nature conservation. International Journal of Biodiversity Science, Ecosystem Services \& Management 7: 301-318. 
Matten, D., Crane, A. and Chapple, W. 2003. Behind the mask: Revealing the true face of corporate citizenship. Journal of Business Ethics 45: 109-120.

Mazurkiewicz, P. 2004. Corporate environmental responsibility: Is a common CSR framework possible. World Bank. http://siteresources.worldbank.org/EXTDEVCOMSUSDEVT/ Resources/csrframework.pdf/ (accessed 29 October 2014).

Mbeki, T. 2004. I am an African. International Journal of African Renaissance Studies 1: 5-13.

Montiel, I. 2008. Corporate social responsibility and corporate sustainability separate pasts, common futures. Organization \& Environment 21: 245-269.

Newell, P. and Frynas, J.G. 2007. Beyond CSR? Business, poverty and social justice: an introduction. Third World Quarterly 28: 669-681.

Ogilvyearth Company. 2011. South Africa Sustainability Survey. http://www.ogilvyearth. co.za/wp-content/uploads/2011/09/Sustainability-Survey-Results.pdf /(accessed 29 October 2014).

Parr, M. and Simons, H. 2007. Business \& biodiversity. A guide for Netherlands based enterprises operating internationally. Amsterdam: International Union for Conservation of Nature and Natural Resources (IUCN).

Pick 'n Pay. 2013. Sustainable living Report 2013. http://www.picknpay.co.za/picknpay/ action/media/downloadFile?media_fileid=28740/ (accessed 29 October 2014).

Porritt, J. 2001. The world in context: beyond the business case for sustainable development, HRH The Prince of Wales's Business \& the Environment Programme - Cambridge Programme for Industry. http://www.cisl.cam.ac.uk/ /media/Files/Complete $\% 20$ publications $\% 20$ for $\% 20$ download/The_World_in_Context.ashx/ (accessed 29 October 2014).

Prieto-Carrón, M., Lund-Thomsen, P., Chan, A., Muro, A. and Bhushan, C. 2006. Critical perspectives on CSR and development: what we know, what we don't know, and what we need to know. International Affairs 82: 977-987.

Republic of South Africa. 2012. National Biodiversity Association Report. Pretoria: Government Printers.

Siddiqui, J. 2013. Mainstreaming biodiversity accounting: Potential implications for a developing economy. Accounting, Auditing \& Accountability Journal 26: 779-805.

Snep, R., Van Ierland, E. and Opdam, P. 2009. Enhancing biodiversity at business sites: What are the options, and which of these do stakeholders prefer? Landscape and Urban Planning 91: 26-35.

Taylor, I. and Williams, P. 2001. South African Foreign Policy and the Great Lakes crisis: African renaissance meets vagabondage politique? African Affairs 100: 265-286.

TEEB. 2010. The economics of ecosystems and biodiversity. See Bishop et al.

Tikly, L. 2003. The African Renaissance, NEPAD and skills formation: An identification of key policy tensions. International Journal of Educational Development 23: 543-564.

UNEP. 2011. Restoring the natural foundation to sustain a Green Economy: A centurylong journey for Ecosystem Management. UNEP Policy Series. Policy Brief 6. http:// www.unep.org/ecosystemmanagement/Portals/7/Documents/policy\%20series\%206.pdf/ (accessed 29 October 2014). 